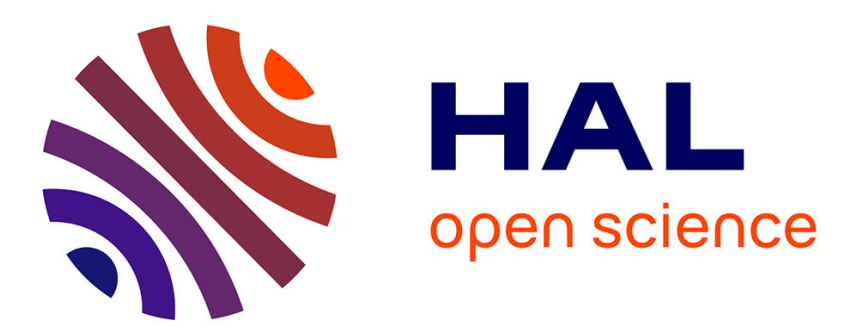

\title{
Changes in the French defence innovation system: New roles and capabilities for the Government Agency for Defence
}

\author{
Nathalie Lazaric, Valérie Mérindol, Sylvie Rochhia
}

\section{- To cite this version:}

Nathalie Lazaric, Valérie Mérindol, Sylvie Rochhia. Changes in the French defence innovation system: New roles and capabilities for the Government Agency for Defence. Industry and Innovation, 2011, 18 (5), pp.509-530. 10.1080/13662716.2011.583464 . hal-00599727

\section{HAL Id: hal-00599727 https://hal.science/hal-00599727}

Submitted on 10 Jun 2011

HAL is a multi-disciplinary open access archive for the deposit and dissemination of scientific research documents, whether they are published or not. The documents may come from teaching and research institutions in France or abroad, or from public or private research centers.
L'archive ouverte pluridisciplinaire HAL, est destinée au dépôt et à la diffusion de documents scientifiques de niveau recherche, publiés ou non, émanant des établissements d'enseignement et de recherche français ou étrangers, des laboratoires publics ou privés. 
Changes in the French defence innovation system:

New roles and capabilities for the Government Agency for Defence

LAZARIC Nathalie*, MERINDOL Valérie**, ROCHHIA Sylvie*

\author{
*University of Nice Sophia Antipolis, GREDEG, Lazaric@ gredeg.cnrs.fr \\ *University of Nice Sophia Antipolis, GREDEG, Rochhia@gredeg.cnrs.fr \\ **Paris Dauphine University, IMRI, valerie@merindol.net
}

\begin{abstract}
:
Defence innovation systems are structured around two main groups of players that interact in the development of complex programmes: the state (the client and the government agency) and the systems integrators. Technological and institutional changes since the 1990s have affected the division of labour and knowledge in the industry. In this paper we show the origins of these changes based on information derived from 45 qualitative interviews conducted between 2000 and 2008, which demonstrate the new capabilities that have been created within the national innovation system (NIS). We explain how the role and the capabilities of the French Government Agency for Defence (Direction Générale de l'Armement - DGA) have developed from «project architect » to "project manager ». These new capabilities create new interactions in the French Defence innovation system and new roles for the DGA.
\end{abstract}

Key words: Technological systems, Capabilities, Knowledge, Government agency, Coevolution, National Innovation System, Defence, Institutional Change. 


\section{Introduction}

The defence industries in most countries are led by two main actors, firms as the systems integrators, and the state and the government agency, which play an important role in the coordination of complex products and systems (CoPS). In France, traditionally the French Defence Agency (Direction Générale de l'Armement - DGA) played a fairly critical role in the design of defence programmes. For example, it facilitated the emergence in the 1960s of a high technology industry with the capacity to elaborate and monitor all French military programmes (Serfati, 2001, 2008).

In the ten years from 1990 to 2000 , some important technological and institutional changes led to profound transformations in the relationship between firms and the DGA. Both technological and institutional factors played central roles in this evolution because the design and production of weapons necessitates the elaboration of rules that facilitate the development of sustainable relations and the transfer of knowledge.

Debate on the defence industry frequently has tried to identify the triggers and sources of change. Two sources have been suggested: the national innovation system (NIS) and the sectoral system of innovation (SSI). James (2000: 96) argues that 'a purely national perspective is no longer appropriate for the study of the UK defence industry. Indeed it probably never has been', while others (Guillou et al., 2009) maintain that the NIS still plays a critical role in the defence industry. Beyond the immediate lack of agreement over institutional and technological factors, the debate is rather nuanced and is more consensual. For instance, James (ibid) also acknowledges that it is the co-evolution of national, sectoral and technological systems that has shaped the defence industry, which lies at the intersection 
among these innovation systems. The contribution of these systems is emphasized by Malerba (2004) who considers that SSI have a knowledge base, technologies, input and (existing or potential) demand. The sectoral systems agents are organizations and individuals. Malerba shows that their interactions are shaped by institutions (rules and regulations) and that these systems are transformed by pressure from a variety of factors. Over time, the existing SSI has undergone transformations through the co-evolution of its various elements. According to Malerba, this implies that a sectoral system is a collective, emergent outcome of the interactions and co-evolution of its various elements. Co-evolution is defined 'not in a restricted sense that two things are evolving together but in the broader sense that multiple things are jointly evolving' (Murmann, 2003: 21).

Dosi and Nelson (2010) highlight the way that the industry dynamics is driven by the coevolution of technologies and institutions, and invite us to decipher the connections within innovations systems and the rest of the economy. The interactions between technology and institutions, and their interlocking elements and processes, are a potential source of inertia and transformative pressure. For instance, within the American NIS, transformative pressures led to the emergence of a new SSI around 'ICT business' and, since 9/11, to the reinforcement and enlargement of the defence industry through the creation of new government agencies ${ }^{1}$ (Hart, 2009).

The path dependence and interlocking forces within such systems are not definitely established and policy makers can play an active part in social redistribution, the social welfare system and the potential impact of a process of 'destructive creation' (Metcalfe \& Ramlogan, 2008). The globalization of production is one such transformative pressure in the defence industry. It generates changes in the division of labour and has huge impacts on the state, which, paradoxically, remains the main actor within this system especially in relation to security (Brooks, 2007). This evolution opens the way to a range of interventions related to 
education and training systems, labour market institutions, financial systems and science and technology systems, to counterbalance any potential inertia that might impede these changes (Lorenz \& Lundvall, 2006). In the defence industry, path dependence is a reality (Serfati, 2000). Recent trends in the NIS have led to new interactions and new connections within and between systems, whose internal and external sources need to be observed and interpreted (Mustar \& Larédo 2002; Guillou et al., 2009). This article is one of what is a very few empirical studies on this area, despite the importance of the defence industry in the French NIS.

We show how the co-evolution of technological and institutional elements has led to interactions within the NIS and a repositioning of the DGA through the evolution of its capabilities. The present research is based on a series of 45 qualitative interviews conducted between 2000 and 2008 with a range of organizations, including suppliers to the DGA, firms involved in complex products and systems (CoPS) and research and development (R\&D) centres working on defence industry and DGA programmes (see annex 2).

Section 2 discusses the technological factors that have contributed to the emergence of a new defence industry architecture. Section 3 focuses on the various sources of institutional changes within the NIS and the DGA, and examines the effects of potential sources of inertia. Section 4 examines the transformations in the DGA's capabilities; Section 5 concludes by highlighting some of the consequences of the profound changes that have taken place in the DGA, for the French defence industry as a whole. 


\section{2: Changes in technological systems}

The defence industry is characterized by a hierarchical division of labour between state-client, firms as systems integrators and sub-contractors, and programmes - most of which are defined as complex (Davies \& Hobday, 2005). This architecture has undergone some major changes in recent years, which have led to opportunities for some organizations, but have forced others to try to protect themselves from this external turbulence in order to survive. The technological complexity brought by the mass implementation of information and communication technologies (ICT) in weapons systems is emblematic of the changes that have taken place within defence technological systems. This has led to a clarification of the roles of the state and firms in programme development. Because knowledge and capabilities have become more and more widely distributed, the design and development of an armaments programme often requires new interactions between public and private actors, which, in turn, often implies new capabilities and new combinations of knowledge among these actors.

\subsection{The complexity of technological systems}

In the 1990s, design complexity increased with the development of what can be described as the set of systems that is interconnected by information and communication systems (Matthews \& Collier, 2000). ${ }^{2}$ The uncertainty related to the content of knowledge and the management of information systems has become increasingly crucial for the management of weapons programmes. The French SCCOA (Air Operations Command and Control System) programme is a good example. ${ }^{3}$ This complexity can be depicted in terms of 'depth' and 'breadth'. Depth refers to the analytical sophistication and breadth refers to the range of areas that require investigation (Wang \& Von Tunzelmann, 2000). In other words, depth is related to cognitive complexity, while breadth is related to relational complexity (Boisot \& Child, 1999). 
In the USA, systems integration ${ }^{4}$ traditionally was conducted by the Joint Staff but as a result of technological change this actor no longer has all the capabilities required to accomplish this task on its own (Gholz, 2003). Hence, several organizations are involved, each with distinct capabilities. According to Gholz (ibid: 298) 'this problem suggests that a shift to a truly joint systems approach, incorporating all the nation's military assets, as part of transformation may require establishment of a single, joint acquisition agency to which a single systems of systems integrator could be attached'. Similar technological and organizational issues have arisen in Europe ${ }^{5}$. In the UK, these responsibilities were passed to the private sector in the early 1990s (Walker \& Gummet, 1993). In France the division of labour changed quite radically with the active role of the DGA within the NIS (Guillou et al., 2009).

In the USA and in Europe, the development of systems of systems has emerged in parallel with firms that have assumed the positions of Lead Systems Integrators (LSI) (Bailey Grasso, 2007). LSI are firms that are given the responsibility for defining the technological architecture of a programme, and whose function is to manage and evaluate a project. The role of LSI provides the opportunity for the firm in question to benefit from the value created, but weakens the traditional positions of government agencies such as the DGA. The informational asymmetries between LSI firms and the DGA are increasing and generating tensions. The integrator needs the technological and organizational capabilities to enable the building of absorptive capacity and the ability to pilot the system (Prencipe, 1997; Hobday et $a l ., 2005)$. For LSI firms, systems engineering is no longer limited to the material aspects of systems integration. Contractual arrangements are a central part of programme management. In such a context, the role of the DGA is not limited to the definition of technico-operational requirements, but also includes the writing of contracts between the military services and firms (Flood \& Richard, 2006). In other words, the role of the DGA has become similar to that of the client that attempts to influence the industry through contracts, rules and setting up 
of consortia to encourage cooperation or competition among firms (Depeyre \& Dumez, 2007). In the US for instance, this new capability can be shared among several government agencies (including military labs) (Gholz, 2009). The French context is different because of the existence of the DGA which attempts to develop a shared vision of the defence innovation system. Thus, by facilitating the emergence of similar representations and procedures within the architecture, government agencies, such as the DGA, can improve coordination.

\subsection{Architectural and component knowledge as key elements of organizational capabilities}

The complexity of a product may lie in the number of its components, the diversity of the materials and information inputs, the degree to which systems and sub-systems are clienttailored, and the complexity of the systems architecture $^{6}$ (Hobday, 2000). The nature of the interfaces between these elements is one of the determinants of the complexity of such systems. In the case of weapons systems, there are numerous interdependent sub-systems ${ }^{7}$ (Ulrich, 1995). In France, the division of labour has been progressive since the 1960s with the design of the Mirage IV and the emergence of the status of systems integrator for the firm managing the programme (Versailles, 2005). For several decades, the industry was characterized by a relatively high degree of specialization among firms and government agencies (Avadykian et al., 2005).

For many years, the French state, through the DGA, acted as the owner, and defined the technological architecture of big weapons programmes $^{8}$ (Cohendet \& Lebeau, 1987; Mérindol, 2005a; Belleval, 2006), and was responsible for their design and management. ${ }^{9}$ This allowed it to choose between different scientific and technological options based on cost and military needs. In defining the criteria ex ante and in controlling the division of labour 
among firms, the DGA's role in defining the technical properties of the defence industry has been significant.

In order to understand the functions involved, it is helpful to refer to the architectural knowledge/component knowledge typology proposed by Hobday (1998). The term component knowledge refers to knowledge related specifically to the technological 'bricks' produced by the sub-contractors that are integrated within the system. The systems integration function rests on architectural knowledge, which makes it possible to combine and integrate a large variety of technologies within the design of a complex system. ${ }^{10}$ Architectural knowledge and technological and organizational skills are not separable: the systems integrator needs to possess both in order to be able to integrate and manage the system (Prencipe, 1997; Hobday et al., 2005). Prencipe's (2000) study of the aeronautical industry shows that in order to be able to make any major decision related to architectural knowledge it is necessary to have component knowledge. Thus, Brusoni et al.'s (2001) statement that 'firms know more than they make' is particularly apposite in the case of the defence industry. A firm (or organization) cannot just propose an overall structure for the design of a complex programme; it must be able to choose between the different technological options and enable their evolution. The requisite capabilities - knowledge, experience and skills - of an integrator are:

the capabilities which enable firms, government agencies, regulators, and a range of other actors to define and combine together all the necessary inputs for a system and agree on a path of future systems development. In the narrower sense of firm capability, system integration is concerned with the way in which firms and other agents bring together high-technology components, subsystems, software, skills knowledge engineers, managers, and technicians to produce a product in competition with other suppliers. ... systems integration capability is not merely the counterpart to outsourcing, but the capability needed to manage outsourcing as well as 'joint sourcing' and 'insourcing' to enable the systems integrator firm to gain the advantages of both outsourcing and vertical integration through different phases of the product life cycle (Hobday et al., 2005: 1110-1111). 
As the technological complexity of products increases, coordination costs increase. Thus, any change to the 'design' or the subcontractors may cause important alterations to the component knowledge. This relational and cognitive complexity has pushed DGA to revise its traditional way of doing things and re-think its role within the defence innovation system. Section 3 discusses the institutional sources of changes which have had a major impact inside the NIS.

\section{Institutional changes inside the NIS}

Seo and Creed (2002) emphasize that the potential rupture between institutional legitimacy and technological efficiency leads to the perception that institutional rules are no longer coherent with organizational survival. The various reforms of the DGA conducted in 1997 and 2003 were implemented precisely to minimize this potential split and modify interactions and interlocking forces in the NIS (Mustar \& Larédo 2002; Guillou et al, 2009). However, the impacts of the 1997 reform, driven mainly by budget constraints, have led to deep transformations within and huge opportunities for firms. For the DGA, interactions with the science and technology system have modified the content of its technological capabilities and architectural knowledge.

\subsection{The 1997 reform: break from a state controlled market}

Until the mid 1990s, defence industry contracts were characterized by state controlled markets and near automatic application of the 'cost plus' rule ${ }^{11}$ (Chesnais \& Serfati, 1992; Hartley, 1995). This policy of 'additional cost' was to preserve independence and avoid the loss of key technological capabilities. However, the costs and delays associated with the end of the Cold War, coupled with reduced national funding, made difficult the persistence of this kind of policy. As competition increased, the DGA was given the discretion to choose among 
domestic firms. ${ }^{12}$ In most cases, the firm selected was obliged to negotiate a subcontract with some of the unselected prime contractors, which generated new strategic alliances.

\section{New rules concerning armaments acquisition}

The 1997 reform was the result, of a new stage in defence policy making. Military R\&D spending was cut from $€ 4,850$ million in 1996, to $€ 3,636$ million in 2004 (both at 2004 constant rates). The proportion dedicated to Research and Technology (R\&T) decreased from $€ 650$ million in 1996 to $€ 380$ million in 2004 (both at 2004 constant rates), a reduction of almost 50\% in less than 10 years. The 1997 reform was also a consequence of a major change within the NIS (Larédo \& Mustar, 2001) and led to the emergence of new policy making priorities. The privatization and tentative Europeanization of firms enabled new relationships within the defence industry (Guillou et al., 2009).

All these changes led to the introduction of new criteria for the selection of firms, notably the best cost/quality ratio. Consequently, firms were obliged to implement new designs for $\mathrm{R} \& \mathrm{D}$ programmes on the basis of fixed price contracts, and to support greater financial and technological risks. This policy evolution was inspired by the 'Levene' reform implemented some years earlier by the UK Ministry of Defence. In France, the DGA's autonomy in weapons systems concepts, which had been one of the founding values of this government agency, came to an end. The principle of a competitive market, open to participation from foreign - mostly European - firms implied the implementation of new 'market' relations between the Ministry of Defence and French domestic firms (DGA, 1997). Thus, the new rules of the game have inexorably reduced the informal exchanges between the DGA and firms (Kirat et al., 2003), although persistent 'lock in', in the form of export agreements between companies, and reduced technology transfer due to administrative requirements, mitigated these transformative pressures (Oudot, 2007). ${ }^{13}$ 


\section{Implications for the division of labour}

The 1997 reform introduced a reorganization of capabilities and assets among firms and government agencies. Firms repositioned themselves along the value chain through a twopronged effort towards greater horizontal integration and greater vertical disintegration, to enhance the benefits from their innovation activities (Dowdall, 2004; Acha \& Brusoni, 2008; Hobday et al., 2005; Guillou et al., 2009). While the role of firms in the realization of advanced defence research programmes was strengthened, the role of the DGA changed to one of following up complex programme developments, and more downstream activities related to testing and trialling (Guichard, 2005). Thus, with the exception of the nuclear sector, firms' interactions with scientific and technologic networks have increased (Mérindol, 2005b).

\section{The positioning of the DGA as a procurement agency}

Pre-1997, the DGA was responsible for the long-term maintenance of industry knowledge. It had a strategic role in the NIS between the Ministry of Defence, the industry and the various scientific networks, based on a complex institutional arrangement among the different organizations dependent on or under the authority of the Ministry of Defence. ${ }^{14}$ The DGA as project owner had a wide range of knowledge and capabilities. From 1997, the DGA became a procurement agency rather than a project-owner. ${ }^{15}$ This introduced a clear separation between technological policy and procurement policy and changed its role to one of organizational supervision rather than the provider of technological expertise (Giovachini, 2000). Technology policy considerations have taken second place to operational needs based on a better cost/quality ratio (Kausal et al., 1999). The 1997 reform is depicted in Graph 1. 


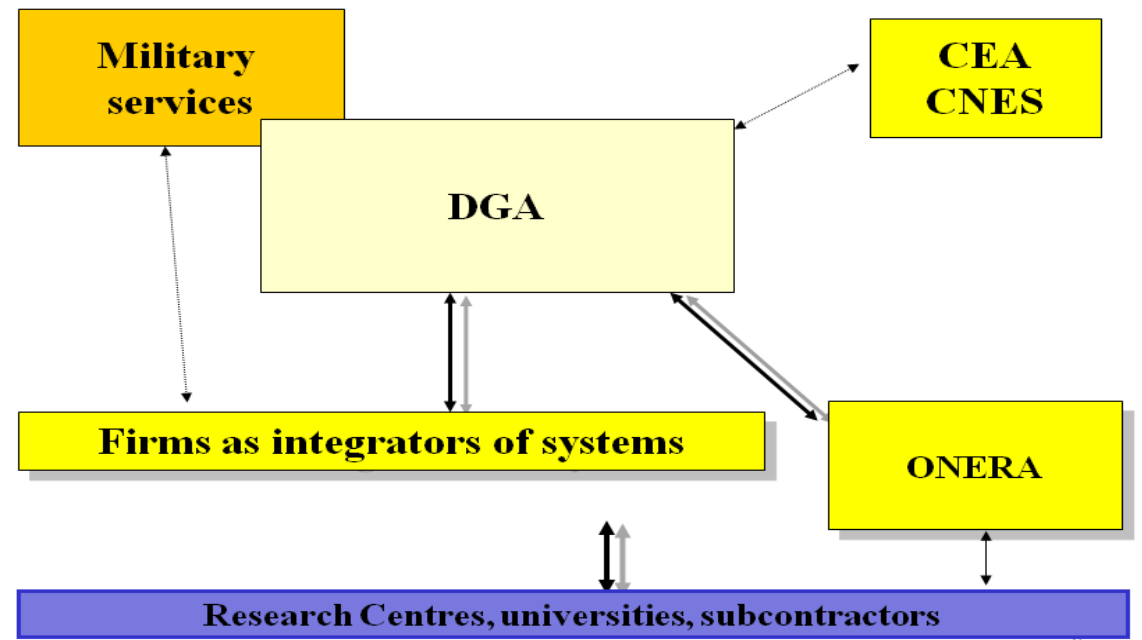

Source: Authors

\subsection{The 2003-04 reform: partnerships and reaffirmation of DGA's role}

A significant loss of architectural knowledge within the DGA (Lignières-Cassou, 2000) led to a re-evaluation in the early 2000 s of arms acquisitions and military R\&D policy. The DGA's strategic role in the defence SSI had become dependent on industry research (Guillou et al., 2009).

\section{Reaffirmation of the DGA's status as project-owner}

The 2003-04 reform introduced new technological responsibilities for the DGA in the development of arms programmes. The maintenance of technological knowledge, required for future programmes, once again became a priority, which resulted in more advanced research. Although this essentially benefited large firms (see Graph 2), the DGA re-launched some exploratory projects with various public and private actors within the NIS (e.g. universities and some small and medium sized enterprises - SMEs) in order to generate new ideas inside the defence innovation system. However, these initiatives were not enough to reposition the 
DGA in the French NIS. ${ }^{16}$ The provision of new defence funds and this technology policy has generated renewed opportunities for the DGA to resume prior relationships with government agencies and firms. ${ }^{17}$ The role of monitoring the content of technological programmes and especially advanced research has given the DGA new responsibilities in the NIS to understand technological options and to provide feed-back on military needs. The DGA also tried to reaffirm its role in the management of dual-use research projects, ${ }^{18}$ by putting an increased weight on projects financed by the National Research Agency, enabling RRIT (Technological Research and Innovation Networks) (Mérindol \&Versailles, 2009), and becoming more involved in poles of competitiveness (Serfati, 2008) (see Graph 2). However, this advanced R\&D is mostly conducted by large firms which have benefited most from this transformation of the NIS (see Graph 2).

\section{Graph 2: Public expenditure on defence related R\&T by beneficiary: \\ $€$ million (2004 constant rate)}

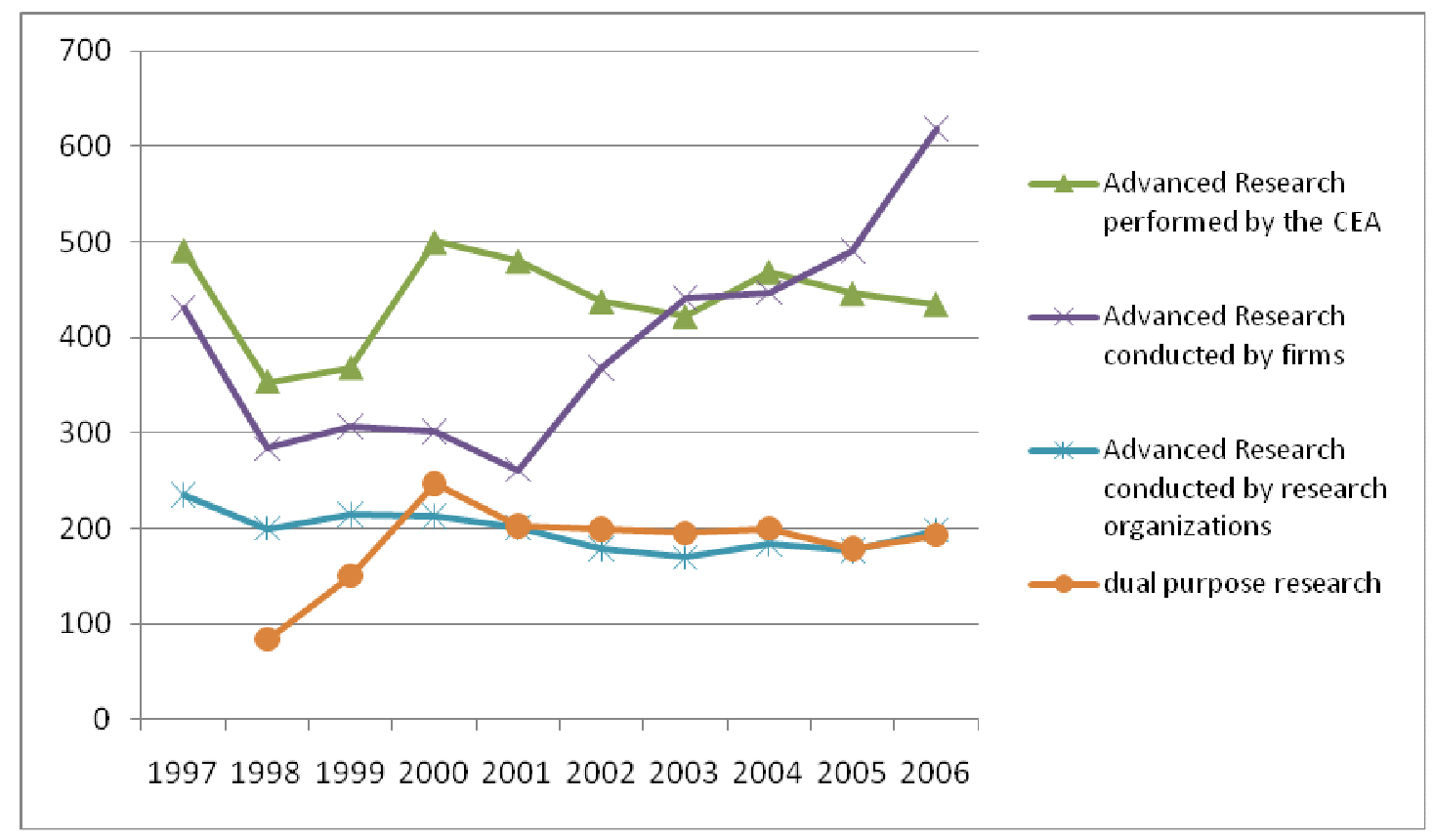

Source: Authors interpretation of DGA and Defence Economic Observatory data 


\section{Difficulties encountered}

The 2003 reform provoked new problems (see Bernard \& Carré, 2005). For instance, In order to monitor advanced research projects DGA requires the right capabilities. ${ }^{19}$ DGA has developed new partnerships with the research centres operating under its authority. These include ONERA, which specializes in research in aeronautics, and the CEA (with DAM specialized in military nuclear systems). ${ }^{20}$ The partnerships developed between the DGA, the CEA and ONERA, correspond to a model of 'externalized absorptive capacity' as defined by Cohen and Levinthal (1990), where the government agency defines the general objectives, the budget, and the allocation of resources, but outsources the architectural knowledge and the management technological networks (to ONERA, CEA/DAM). If these new feedbacks induce government agencies to take into account the evolution of military needs, ${ }^{21}$ the acknowledgment of specific military claims is still faced with coordination problems.

\section{Development of partnerships between the DGA, the military services and the industry}

The 2003 reform enabled the development of new networks and the establishment of relationships between various private and public organizations (see Graph 3). Feedback from government agencies such as CNES, CNRS and INRIA (DGA, 2004, 2006), is illustrative of the interactions around military $R \& D$ projects and the new partnerships between firms and the DGA. Of course existing partnerships with LSI may be questionable, ${ }^{22}$ but the new institutional and technological pressures resulted in a more 'open innovation model' (Chesbrough, 2003).

The creation of 12 technico-operational laboratories ${ }^{23}$ (LTOs) in the Ministry of Defence have facilitated the partnerships between the DGA, the military services and firms, and are representative of the interlocking elements in the open innovation model. LTOs are 
organizational units that implement new technological platforms, involving hybrid forms of R\&D governance, based on market mechanisms and informal relationships. These platforms enable experimentation and simulation of technologies within the framework of operational exercises and encourage feedback between end-users and the suppliers of the technology. They play the role of "cooperative technical organizations" described by Rosenkopf and Tushman (1998), and trigger new interactions in the NIS. LTOs are populated by DGA engineers and senior officers from the military. These specialists are selected according to their specific experience in procurement, in military programme management, or in operational duties. They work in the LTO under special employee lending agreements lasting three years, before returning to their former positions. LTO activities are commissioned and coordinated by the Joint Staff which decides about budgets and technological priorities. Their work must respond to specific military needs such as electronic inter-operability between weapons. Collocating technical and operational experts in the same teams is aimed at fostering interactions and facilitating the exchange of tacit knowledge and critical information to solve specific problems that arise in military operations and that occur after equipment has been tested.

These new collaborations among government agencies are depicted in Graph 3. 


\section{Graph 3 - the 2003 reform \\ intensity of relationships and knowledge exchanges}

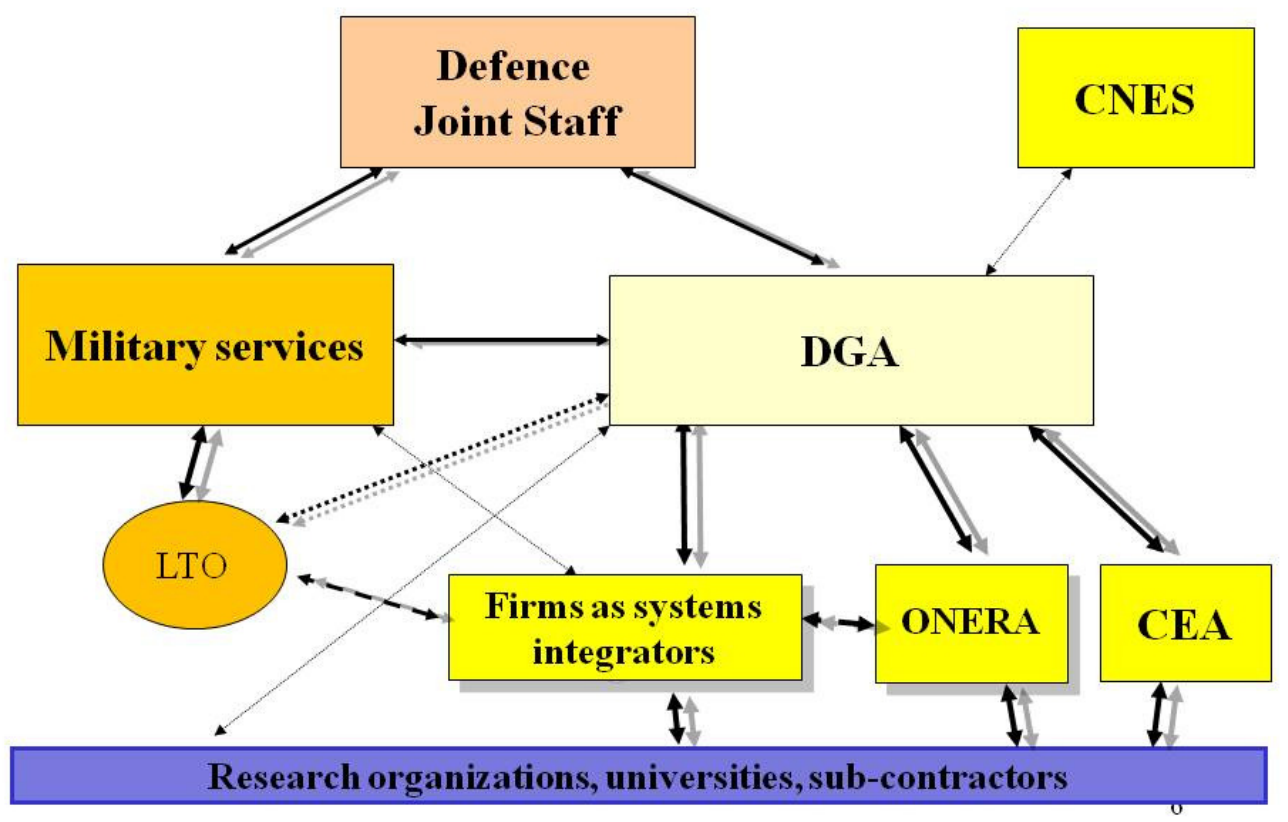

Source: Authors

The intensity of the exchanges between public and private actors, however, is low. Informal relationships between firms and the DGA began to decrease after the 1997 reform while the links between the DGA and the military services increased. The creation of LTOs and the closer relations between operational staff and firms have become sources of uncertainty and have produced organizational inertia in the DGA. The ambiguities related to its future are causing tensions in terms of potential technological and institutional changes, and are making it difficult to make sense of them (for a similar discussion on Europe and the UK, see Fligstein, 2006). The changes are summarized in Table 1. 
Table 1:

The impact of technological and institutional changes for the DGA

\begin{tabular}{|c|c|c|c|}
\hline $\begin{array}{l}\text { Period/ } \\
\text { dimension }\end{array}$ & Pre-1997 & 1997-2003 & Post-2003 \\
\hline $\begin{array}{l}\text { Technological } \\
\text { dimension }\end{array}$ & $\begin{array}{l}\text { - Relative complexity and } \\
\text { industrial stability } \\
\text { - Autonomy of system } \\
\text { components }\end{array}$ & \multicolumn{2}{|c|}{$\begin{array}{l}\text { - Increasing complexity and increasing use of ICT } \\
\text { - } \quad \text { Interdependence of technological systems } \\
\text { - Critical interplay between architectural } \\
\text { knowledge and component knowledge }\end{array}$} \\
\hline $\begin{array}{l}\text { Institutional } \\
\text { dimension }\end{array}$ & - Cost plus contracts & $\begin{array}{l}\text { - Fixed price } \\
\text { contracts } \\
\text { - } \begin{array}{l}\text { Increasing place } \\
\text { for competition }\end{array}\end{array}$ & $\begin{array}{l}\text { Shared technological } \\
\text { and financial risks } \\
\text { between firms and the } \\
\text { DGA } \\
\text { New kinds of } \\
\text { partnerships between } \\
\text { government agencies } \\
\text { and between firms and } \\
\text { the DGA }\end{array}$ \\
\hline $\begin{array}{l}\text { Impacts on the } \\
\text { specialization of } \\
\text { the assets }\end{array}$ & $\begin{array}{l}\text { - Stable co-specialization } \\
\text { - Stable division of labour } \\
\text { between firms and } \\
\text { government agencies }\end{array}$ & \multicolumn{2}{|c|}{$\begin{array}{l}\text { - } \quad \text { Various forms of co-specialization of assets } \\
\text { Emergence of new capabilities and new } \\
\text { partnerships for building assets }\end{array}$} \\
\hline
\end{tabular}

Source: Authors

\section{Inertia, changes and emergence of new capabilities within the DGA}

The traditional role of the DGA as project-owner and co-designer of technological programmes has evolved significantly. In no longer being the privileged player within the defence SSI, the DGA's range of capabilities has been questioned, which has challenged the founding values of the NIS, notably the recruitment of engineers.

\subsection{From project architect to project manager: evolution of DGA's capabilities}

Until the early 1990s, the DGA occupied a central position in the design of weapons programmes and acted as the interface between firms and the military service. In its capacity 
as project-owner, it played an active part in the design of these programmes. In the 1970s, the DGA was able to monitor exploratory projects using in-house expertise, although it outsourced development and production to firms (Mérindol, 2005a). When DRET (Directorate for Research and Technical Studies) was part of the DGA,${ }^{24}$ the DGA's role as the national technical and scientific authority was unquestioned.

Although the DGA was the project architect; its monitoring role was not limited to architectural knowledge; it also had close relationships with suppliers and subcontractors which enabled a good understanding of component knowledge. In order to maintain this role, the DGA was forced to increase the range of its technological knowledge. The function of project architect also had a major impact on the division of knowledge, for instance, the ability to co-specify and influence technical solutions.

In the 1997 reorganization, the DGA's DRET was dismantled and DGA became more of a procurement agency. The institutional changes during the 1990s underline this. Firms were given greater autonomy and new opportunities for the development of new technological and organizational capabilities (Guillou et al., 2009). Despite its critical role as technical expert, the range of DGA's capabilities and especially its architectural knowledge, progressively decreased (Mérindol, 2005a). The loss of $30 \%$ of its workforce ${ }^{25}$ and the reduction in its operating costs accelerated this downward trend. The role of firms increased, especially in terms of their involvement in design and R\&D (see Graph 2). ${ }^{26}$ Eventually, the DGA was unable to monitor the evolution of architectural knowledge because its effective participation had decreased and it had no opportunity to develop new capabilities.

The 2003 reform allowed the DGA to reposition itself within the NIS and it was given the task of translating military needs into technical specifications. This is a highly complex task because of the increasing variety of the missions assigned to the military services and the 
impacts on weapons systems performance and programme costs. DGA's current responsibilities require appropriate knowledge to identify firms' capabilities, and a good understanding of the financial and organizational implications of technological choices. Its ability to identify the capabilities associated with individual firms is essential in order to define the sub-systems composing CoPS, even though programme architecture can no longer be an in house responsibility.

The DGA has shifted progressively from design related activities to management of CoPs. Its activities involve the definition of specifications, rules and modes of control, and monitoring. These evolutions are summarized in Table 2.

Table 2:

\section{Changes in DGA's capabilities}

\begin{tabular}{|c|c|c|c|}
\hline $\begin{array}{c}\text { Period } \\
\text { Main } \\
\text { capabilities }\end{array}$ & Pre-1997 & 1997-2003 & Post-2003 \\
\hline $\begin{array}{l}\text { Organizational } \\
\text { capabilities }\end{array}$ & $\begin{array}{c}\text { Priority to co-design } \\
\text { activities } \\
\uparrow \\
\text { Project architect }\end{array}$ & $\begin{array}{c}\text { Priority to procurement } \\
\text { activities } \\
\uparrow \\
\text { Procurement agency }\end{array}$ & $\begin{array}{c}\text { Priority to monitoring and } \\
\text { technological control } \\
\uparrow \\
\text { Project manager }\end{array}$ \\
\hline $\begin{array}{l}\text { Technological } \\
\text { capabilities }\end{array}$ & $\begin{array}{c}\text { Upstream approach } \\
\uparrow \\
\text { R\&T management }\end{array}$ & $\begin{array}{c}\text { Downstream approach } \\
\uparrow \\
\text { Product Management } \\
\text { Management of outsourced } \\
\text { research }\end{array}$ & $\begin{array}{c}\text { Partnership approach } \\
\uparrow \\
\text { Management of various } \\
\text { networks for maintaining an } \\
\text { externalized absorptive } \\
\text { capacity }\end{array}$ \\
\hline
\end{tabular}

Source: Authors

Thus, the changes in the DGA reflect the new kinds of interactions within the NIS and are generating new capabilities. The 1997 reform marked the beginning of a shift in the model from 'project architect' to 'project manager'. 


\subsection{New values and new skills for the armaments engineering workforce}

Changes generate uncertainty and the need for adjustment. The literature on organizational inertia shows that effective implementation of change may be difficult. Hannan and Freeman (1977, 1984), observing large populations of organizations, show that size and age may be important reasons for preserving the status quo in an organization. The notion of 'imprinting' developed by Stinchombe (1965), illustrates that initial values may create strong path dependencies for the implementation of future organizational developments (Aldrich, 1999). That is, the values and goals of the organization's founder may result in a coherent organizational culture and a keenness to maintain these values (Cyert \& March, 1963), which may be linked to existing resources and existing coalitions and may constitute a form of organizational truce and a reason for continuing existing routines (Nelson \& Winter, 1982; Howard-Greenville, 2005). As Nelson and Winter explain, individual skills, organizational routines and capabilities are sources of the stability that is necessary for the achievement of a degree of routinization in organizations (see also Dosi et al., 2008, for a longer discussion). In short, individual level skills are the basis for robust organizational level routines and capabilities. Transformations are defined as major or substantial changes in organizations. But 'to qualify as transformations, changes must involve a qualitative break with routines and a shift to new kinds of competencies that challenge organizational knowledge' (Aldrich, 1999: 163). Thus, changes may have various outcomes, which may involve new definitions of goals, boundaries and activity systems (Aldrich, ibid).

For the DGA, these changes implied new forms of interactions within the NIS. Increased expertise required the accumulation of competencies, which need to be preserved over time. In this context, test centres play a key role in maintaining the minimal capabilities allowing for the management of weapons programmes' specifications and conception. As in-house 
R\&D has never been a priority for DGA (see Graph 4), these centres are the locus for dialogue between industry and the DGA.

Graph 4: Percentage of in house $R \& D$ performed internally by the DGA

(in millions of euros - 2004 constant rates)

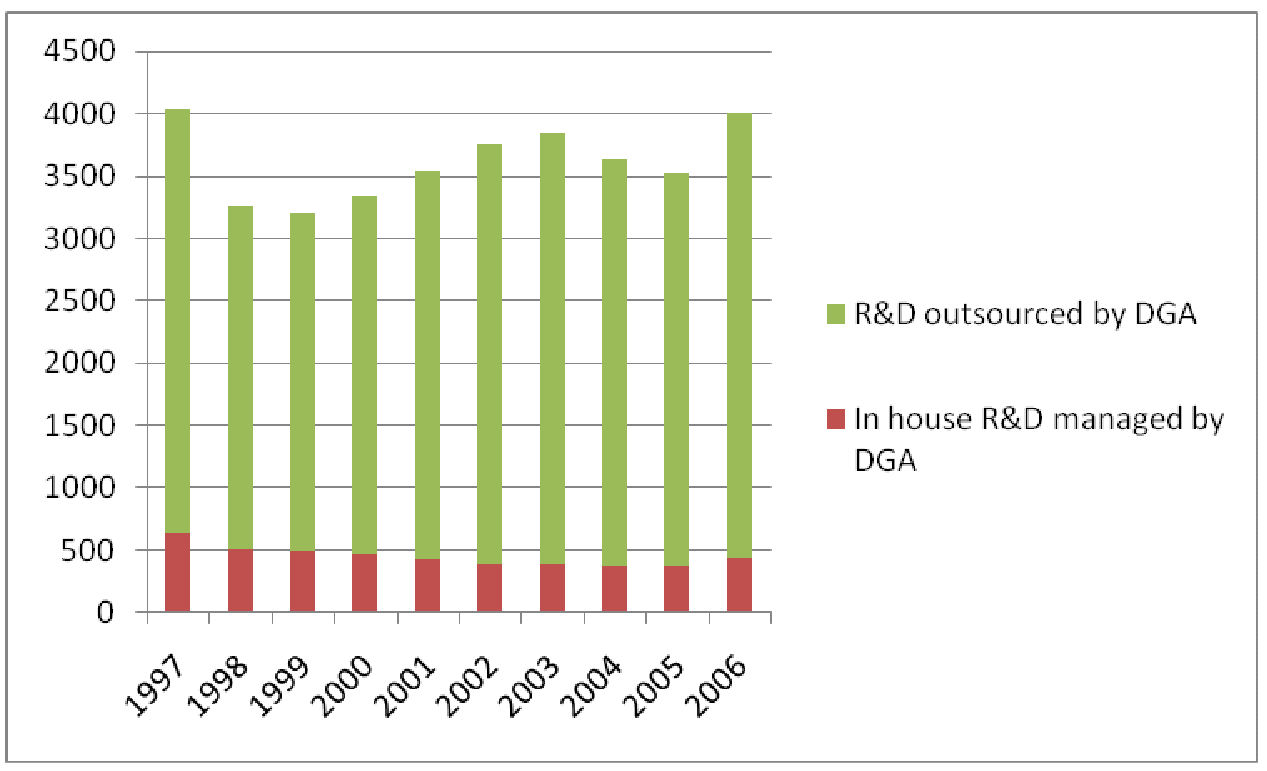

Sources: Based on DGA and Defence Economic Observatory, and authors' calculations

On the other hand, DGA's expertise and evolution cannot be understood without reference to the recruitment of highly qualified graduates from the Ecole Polytechnique (one of the most prestigious French engineering schools). The 'esprit de corps', as Kessler (2005) describes it, is very strong, and within the French education and research systems creates a sort of Balkanization in which some schools/disciplines try to defend their prerogatives (Verdier, 2006). Armaments engineers have a shared set of values based on their history, on myth, on the technical culture and a common language, and the representation of their role in the NIS. Up to the early 1990s, these engineers were at the heart of the innovation networks and weapons design systems. The informal relations among armaments engineers and firms were 
dense and were based on tacit rules. ${ }^{27}$ This created path dependency since the defence innovation systems is very compartmentalized and 'each governmental agency is keen not to lose its core competencies to another agency, manager recruitment in each agency comes mainly from the different and rival polytechnic high schools' grand corps (...); and finally the core of the FSI (French System of Innovation) is located in the aerospace, nuclear and arms industries' (Serfati, 2000: 79).

During the period of the Cold War, the acquisition of scientific and technical expertise by DGA's engineers depended on multiple exchanges between the DGA and firms. Following the 1997 reform and the shift in the DGA's role to procurement, ${ }^{28}$ the DGA's armaments expertise was called into question. Although the 2003 reform can be seen as an attempt to reinforce some of DGA's technological capabilities, it can also be seen as a step back by arms engineers, based on the increasing and direct involvement of the military services in the management of the programmes that it promoted.

In the course of this evolution, the work of DGA's engineers, in particular, shifted from design to planning and management of advanced research projects. By outsourcing rather than conducting CoPS, skills were lost. Some organizational capabilities were transferred to firms (Guillou et al., 2009), decreasing the DGA's critical role in systems integration. The DGA was no longer able to preserve in-depth capabilities. It needs to maintain the knowledge required to identify firms and/or research centres ${ }^{29}$ where design and production can be performed most effectively (Prencipe, 2000).

\subsection{Changes to the content of DGA's capabilities}

In this new context, DGA must be able to identify knowledge critical for the development of programmes, and to create networks within the NIS. It is clear that the transition from 'project 
architect' to 'project manager' is not automatic and involves choices, and the definition of new priorities, in order to maintain certain organizational and technological capabilities. The capabilities of a project architect vary depending on the degree of standardization of the subsystems. However, a certain level of knowledge about the functional characteristics of subsystems is indispensable. These capabilities depend also on the ability to translate operational needs into technological products. Project management encompasses the development and follow up of technical specifications. Although actual architectural knowledge may not be required, a good understanding of firms, and the ability to convert military needs into technological solutions, remain necessary. Consequently, since the DGA has become a project manager, its capabilities have had to evolve. For instance, the DGA no longer has to specify the interfaces between components, or even to prescribe the functional characteristics of components. Thus, its system architecture capabilities have tended to decline, and one of the consequences of this change is that the DGA is not the sole and privileged player in the defence innovation system.

Conversely, the capabilities for integration and control, which are organizational capabilities, have become more critical. For the DGA, the main problems involved in system integration lie in the heterogeneity of the resources and competencies that need to be mobilized. This heterogeneity is described as a 'cognitive' quality because it exists at both the production and knowledge levels. It requires an appropriate division of labour to ensure that the various specialists interact appropriately, and to evaluate their technological, financial and organizational results. Coordination is required to develop a shared vision of a system and to facilitate its integration. Thus, by facilitating the emergence of similar representations and procedures within the architecture, government agencies, such as the DGA, may reduce the cost of exchanging ideas. As illustrated by the design of technological platforms, such as LTO, sharing relates to both representations and tools. This does not eliminate all the 
problems involved in integration, but can reduce their costs significantly. This is precisely the new form of governance that constitutes the important role of the DGA within the NIS and which may help to overcome persistent ambiguities in the definition of military goals and cooperation with various government agencies.

The capabilities required to select firms and to translate military needs into technological solutions are opening new opportunities for armaments engineers to promote their skills. Firms no longer are selected on the basis of technological performance, but on the quality of resource allocation in the implementation of a programme. As project manager, the DGA is more concerned with the number of components in a system and their interlinking, that is, with the degree of heterogeneity in components. As project architect it was more concerned with the level of sophistication of the knowledge embodied in components. The DGA requires a wide spectrum of knowledge and needs to be knowledgeable about the different firms in the innovation network in order to ensure a satisfactory level of coordination at the various stages of programme development. When the required components or subsystems are completely new, their selection will generate the creation of new networks. In other words, the need for coordination does not stop at the stages of system definition and technical design. The ability to translate military needs into technical specifications is essential because of the variety of operational languages involved. The DGA may help to reduce the costs of coordination between end-users and the suppliers of technologies. But the organizational capabilities required are challenging for qualified engineers because they differ from the founding values obtained via the French education system, which are based on technical expertise.

Prior to 1997, both project architect and systems integrator required good architectural knowledge because they worked collaboratively within a co-specification process. The project architect needed in-depth and wide ranging knowledge on the co-design of programmes, 
which allowed it to translate military requirements into technological specifications. This capability enabled the selection of firms and controlled their integration. The position of project manager requires the same capabilities. Therefore, if the architectural knowledge has been transferred to firms, the project manager requires some capability for integration in order to select firms and translate military needs, and maintain access to a wide range of knowledge. Though the breadth of this knowledge remains critical, the trade off between breadth and depth is a challenge for the DGA, firms and other government agencies. In this context, organizational capabilities are critical for resolving conflicts in the interactions and ambiguities among various actors. Table 3 summarizes these issues for the DGA.

Table 3: Content of capabilities for the DGA

\begin{tabular}{|c|c|c|}
\hline $\begin{array}{c}\text { Period } \\
\text { Content of capabilities }\end{array}$ & $\begin{array}{c}\text { Before } 1997 \\
\text { Project architect }\end{array}$ & $\begin{array}{c}\text { After } 2003 \\
\text { Project manager }\end{array}$ \\
\hline Core capabilities & $\begin{array}{l}\qquad \text { Architectural capabilities: } \\
\text {-Integration capabilities } \\
\text {-Capabilities to select firms } \\
\text {-Capabilities to translate military needs into } \\
\text { technological specifications }\end{array}$ & $\begin{array}{l}\text { Management capabilities: } \\
\text {-Capabilities to select firms } \\
\text {-Contract capabilities } \\
\text {-Capabilities to translate military needs } \\
\text { into technological specifications }\end{array}$ \\
\hline Main capabilities & Technological and organizational & Organizational \\
\hline Evolution of capabilities & Breadth and depth & Priority on breadth \\
\hline
\end{tabular}

Source: Our research 


\section{Conclusion}

By generating new modes of interactions and new interlocking forces, the technological and institutional changes within the NIS have had a major impact on the defence innovation system. In this more open innovation model (Chesbrough, 2003), the role and capabilities of each actor have been modified. Based on the reinforcement of the role of large firms in systems integration, these firms have acquired a central position which has been strengthened through state funded, advanced research projects. With the implementation of new research and innovation policies, these firms have benefited from the transfer of new knowledge, and have gained greater autonomy. The DGA, in order to maintain its position as a significant player within the NIS and, more importantly, to maintain a minimum level of expertise, has implemented a large number of co-specialized assets (e.g. LTOs). As firms have become more able absorb new capabilities to produce innovations responding to the technological and organizational characteristics of CoPs, DGA's influence within the NIS has been reduced in favour of various other government agencies. In order to maintain minimal absorptive capacity and capabilities, the DGA has had to increase its interactions with private and public organizations.

The shift from project architect to project manager implies not only new capabilities, but also new goals, values and resources. New institutional rules may be difficult to implement when the founding values of the French educational systems are being questioned. This explains why, since 2003, the DGA has tried to avoid remaining a mere procurement agency and is making active efforts to maintain a high level of technical expertise and organizational capability through the development of new forms of networks. New forms of partnerships are necessary to ensure the monitoring, sustainability and maintenance of complex projects, and are vital for this government agency's continued critical role in the NIS. Thus, the evolution 
of capabilities is taking place within the French NIS, but prior competencies tend to create 'core-rigidities', creating additional sources of inertia inside the French defence innovation system and, consequently, mitigating earlier changes. 
Annex 1: List of acronyms

CEA Atomic Energy Commission (Commissariat à l'Energie Atomique)

CGARm General Council of Armament (Conseil Général de l'Armement)

CNES National Space Study Center (Centre National d'Etudes Spatiales)

CNRS National Scientific Research Centre (Centre National de Recherches Scientifiques)

CoPS: $\quad$ Complex products and systems

DAM: Military Applications Directorate of the CEA (Direction des Applications

Militaires du CEA)

DGA Government Agency for Defence (Direction Générale de l'Armement)

DRET Directorate for Research and Technical Studies (Direction de la Recherche et des Etudes Techniques)

EADS European Aeronautic Defence and Space Company

EDA European Defence Agency

ICT : $\quad$ Information and Communication Technologies

INRIA National Institute for Computer Science and Control (Institut National de

Recherche en Informatique et en Automatique)

LSI Lead System Integrator

LTO Technical and Operational Laboratories (Laboratoires Technico-Opérationnels)

MoD Ministry of Defence (UK)

NIS National Innovation System (Système National d'Innovation)

OED Economic Defence Observatory belonging to the French Defence Ministry

(Observatoire Economique de la Défense)

ONERA French Aeronautics and Space Research Centre (Office National d'Etudes et de Recherches Aérospatiales)

RRIT Technological Research and Innovation Networks (Réseaux de Recherche et d'Innovation technologiques )

R\&D Research and Development

R\&T Research and Technology

SCCOA Air Operations Command and Control System (Système de Communication et de Commandement des Opérations Aériennes)

SSI

Sectoral System of Innovation 


\section{Annex 2: Methodology}

This research is based on 45 qualitative interviews conducted between 2000 and 2008 with a range of respondents, including suppliers to the DGA, firms involved in CoPS and R\&D centres working for the defence industry and commissioned for DGA programmes. Interviews were conducted in the framework of various projects such as:

-Projects commissioned by the Observatory for Defence economics (OED): Innovation, diffusion of knowledge and growth: the case of firms related to defence industry, Guillou et al. (2005); and the Typology of firms defence related competencies : analysis of codified and un-codified competencies, Guillou et al (2007).

-Project commissioned by the EDA: How to measure the strengths \& weaknesses of the DTIB in Europe, with Manchester Institute of Innovation Research (2008)

- Project commissioned by the OED (2001-2003): Defence R\&D policy : Prospective about the interaction between Stages and the Defence industry (Mérindol et al).

- Project commissioned by the French Air Force staff to the Research Centre of the French Air Force (2004-2006): Defence-related integration activities and key organizational and technological competences.

These face to face interviews were semi-structured and lasted an average of two hours. The questions asked about interviewees' backgrounds and their perspectives on the defence industry, and their understanding of the DGA and its evolution over time. Each interview report was validated by the interviewee.

Data for the projects were enriched by the contribution of one of the authors to several expert groups on the evaluation of armament programmes between 2001 and 2006 developed for the Defence Economics Council and the Armament General Advisory Board. This enabled a better understanding of the strategic issues involved in the repartition of institutional prerogatives within the French Ministry of Defence, especially between the DGA, the armed services and the industry. The results of these projects and investigations were presented at workshops organized by the French Ministry of Defence (OED; Defence Economics Council; Armament General Advisory Board; DGA Scientific and Technological Foresight Board). 


\section{References}

Acha V. and Brusoni S. (2008) The changing governance of knowledge in avionics, Economics of IOnnovation and New Technology, 17, (102), pp.43-57.

Aldrich H. (1999) Organizations Evolving, Sage Publications, London.

Avadykyan A., Cohendet P., and Dupouet O. (2005) A study of military innovation diffused based on two case studies, in Llerena P. \& Matt M. (ed), Innovation Policy in a Knowledge Based Economy, Germany: Springer pp.161-189.

Bailey Grasso V. (2007) Defense acquisition: use of lead system integrators (LSIs) background, oversight issues and option for congress, CRS Report for Congress, the library of Congress, Washington, 26 mars.

Belleval C. (2006) De la remise en question des pratiques des grands projets de haute technologie d'Etat à celle des missions du maître d'ouvrage : le cas d'un programme spatial, $\mathrm{n}^{\circ}$ spécial en l'honneur de Fernand Amesse, Management International $\mathrm{n}^{\circ} 10$, pp. $55-64$.

Bernard J.L and Carré A. (2005) Les conditions d'exécution des grands programmes de Défense, Rapport d’information n¹922, Assemblée Nationale 12ème législature, Paris.

Boisot M. and Child J. (1999) Organizations as adaptive systems in complex environments: the case of China, Organization Science, vol. 10, no. 3, pp.237-252.

Brooks S.G (2007) Producing Security: Multinational Corporations, Globalization, and the Changing Calculus of Conflict, Princeton University Press, Oxford

Brusoni S., Prencipe A. and Pavitt K. (2001) Knowledge specialization, organizational coupling, and the boundaries of the firm: why do firms know more than they make?, Administrative science quarterly, 46 (4), pp.597-621.

Cohen W. and Levinthal D. A. (1990) Absorptive capacity: a new perspective on learning and innovation, Administrative Science Quarterly, 35 (1), pp.128-152.

Chesbrough H. (2003) Open Innovation: the New Imperative for Creating and Profiting Technology, Boston: Harvard Business School Press.

Chesnais F.and Serfati C. (1992) L'armement en France : genèse, ampleur et coût d'une industrie, coll. Economie et sciences sociales, Paris : Nathan.

Cohendet P., Lebeau A. (1987) Choix stratégiques et grands programmes civils, Paris : CPEEconomica, 189 pages.

Cyert R. M. and March J.G (1963) A Behavioral Theory of the Firm, Publisher: Englewood Cliffs, N.J., Prentice-Hall.

Davies A. and Hobday M. (2005) The business of projects: managing innovation in complex products and systems, Cambridge: Cambridge University Press.

Délégation Générale pour l'Armement (1997) La réforme de la DGA, revue l'Armement, nºspécial, ministère de la Défense, décembre 1996-janvier 1997.

Délégation Générale pour l'Armement (2004) Pour une autonomie compétitive en Europe : la politique d'acquisition du ministère de la Défense, Ministère de la Défense, http://www.defense.gouv.fr/dga/layout/set/popup/content/view/full/64595. 
Délégation Générale pour l'Armement (2006) Politique et Objectifs Scientifiques, Ministère de la Défense, Paris.

Depeyre C. and Dumez H. (2007) Le rôle du client dans les stratégies de coopétition, Revue française de gestion, 7 (176), pp.99-110.

Dosi G., Faillo M., and Marengo L. (2008) Organizational capabilities, patterns of knowledge accumulation and governance structures in business firms: an introduction, Organization Studies, 29, pp.1165-1185;

Dosi G. and Nelson R. (2010) Technical change and industrial dynamics as evolutionary processes. Forthcoming in B.H. Hall and N. Rosenberg, Handbook of the Economics of Innovation- vol-I, Burlington: Academic Press,/Elsevier, pp.51-128.

Dowdall P. (2004) Chains, networks and shifting paradigms: the UK defence industry supply system, Defence and Peace Economics, 15 (6), pp.535-550.

Flood S. and Richard P. (2006) An assessment of the lead systems integrator concept as applied to the future combat system program, defense Acquisition review journal, December 2005-march 2006, pp. 357-373.

Fligstein N. (2006) Sense making and the emergence of a new form of market governance: the case of the european defense industry. American Behavioral Scientist, 49, pp.949-960.

Fromion Y. (2005) Rapport d'information sur la recherche de Défense et de Sécurité, Assemblée nationale, rapport $\mathrm{n}^{\circ} 2150$, Paris.

Giovachini L. (2000) L'armement français au XXème siècle : une politique à l'épreuve de l'histoire, Les cahiers de l'armement, Paris : Ellipses.

Gholz E. (2003) Systems Integration in the US Defence Industry. What Does It and Why Is It Important, in The Business of Systems Integration, Prencipe A., Davies A., Hobday M. (Eds), pp.279-306.

Gholz E. (2009) Systems integration for complex defense projects, in Organizing for a complex word: Developing Tomorrow's Defence and Net Centric Systems, Ben-Ari B., Chao A., CSIS, Washington, pp. 50-65

Guichard R. (2005) Suggested repositioning of defence R\&D within the french system of innovation, Technovation, 25(3), pp. 195-201.

Guillou S., Lazaric N., Longhi C., Ngo Mai S. and Rochhia S. (2005) Innovation, diffusion des connaissances et croissance : le cas des entreprises liées à la défense, Rapport O.E.D (Observatoire Economique de la Défense)

Guillou S., Lazaric N., Longhi C., and Rochhia S. (2009) The french defence industry in the knowledge management era: A historical overview and evidence from empirical data, Research Policy, 38, issue 1, 170-180.

Hannan M. and Freeman J. (1977) The population ecology of organizations, American Journal of Sociology, 82, pp.929-64.

Hannan M. and Freeman J. (1984) Structural inertia and organizational change, American Sociological Review, 49, pp.149-164.

Hart D.M. (2009) Accounting for change in national systems of innovation: a friendly critique based on the US case, Research Policy, 38, pp. 647-654. 
Hartley K. (1995) Industrial Policies in the Defense Sector, in Handbook of Defense Economics vol.1, edited by Hartley K. and Sandler T., Elsevier North Holland, pp.459489.

Henderson R. and Clark K.(1990) Architectural Innovation: The Reconfiguration of Existing Product Technologies and the Failure of Established Firms, Administrative Science Quarterly, 35, pp.9-30.

Hobday M. (1998), Product complexity, innovation and industrial organisation, Research Policy, 26, pp. 689-710

Hobday M. (2000) The project-based organization: an ideal form for managing complex products and systems?, Research Policy, 29 (7-8), pp.871-893.

Hobday M., Davies A. and Prencipe A. (2005) Systems integration: a core capability of the modern corporation, Industrial and Corporate Change, 14 (6), pp.1109-1143.

Howard-Greenville J. (2005) The persistence of flexible organizational routines: The role of agency and organizational context, Organization Science, 16(6), pp.618-636.

James A. D. (2000) The Place of the UK Defense Industry in its National Innovation System: Co-evolution of National, Sectoral and Technological Systems. In The place of the defence in National System of Innovation, Reppy J. (ed), Cornell University Press.

Kausal T., Humily G., Taylor T. and Roller P. (1999) A comparison of the Defense Acquisition systems of France, Great Britain, Germany and United States, Defense Systems management college, Virginia, 220605565.

Kessler C. (2005) L'esprit de corps dans les grands corps de l'Etat en France, Working paper du CERSA, Université Paris II Panthéon Assas.

Kirat T., Bayon D. and Blanc H. (2003) Maîtriser les coûts des programmes d'armement : une analyse comparative de la réglementation des marchés industriels d'armement en France, au Royaume-Uni et aux Etats-Unis, Les rapports de l'Observatoire économique de la Défense, Paris : La Documentation française.

Larédo P. and Mustar P. (2001) French Research and Innovation Policy: Two Decades of Transformation, in Larédo P. and Mustar P. (eds.), Research and Innovation Policies in the Global Economy: An international Comparative Analysis, Cheltenham: Edward Elgar, pp. 447-496.

Lignières-Cassou M. (2000) Les études amont des programmes d'armement dans le domaine de la Défense et de l'aéronautique, rapport d'information $\mathrm{n}^{\circ} 2793$, Commission de la Défense nationale, Assemblée Nationale.

Lorenz E. and Lundvall B.A (eds) (2006) How Europe's Economies Learn: Coordinating Competing Models, Oxford, Oxford University Press.

Malerba F. (2004) Sectoral systems: concept and issues,. In Sectoral Systems of Innovation : Concepts, Issues and Analyses of Six Major Sectors in Europe, Malerba F.( ed) Cambridge Books, Cambridge University Press, pp 9-42.

Matthews D., Collier P. (2000) Assessing the value of a C4ISREW System-of-Systems Capability, working paper, Australia: Joint systems Branch DST.

Mérindol V. (2005a) La Défense dans les réseaux d'innovation : une analyse en termes de compétences, Revue d'Economie Industrielle, décembre, pp. 45-64 
Mérindol V. (2005b) Defense R\&DTE and knowledge management: A new inquiry into public-private coordination, Defense and Security Analysis, 21 (2), June, pp.159-177.

Mérindol V. and Versailles D.W (2009) Dual use as knowledge oriented policy: France during the 1990-2000ies, International Journal of Technology Management, vol. 50(1), pp.80-98.

Metlcalfe S. and Ramlogan R. (2008) Innovation systems and the competitive process in developing economies, The Quarterly Review of Economics and Finance, vol. 48(2), pp. 433-446.

Murmann J.P. (2003) Knowledge and Competitive Advantage. The Coevolution of Firms, Technology, and National Institutions, Cambridge: Cambridge University Press.

Mustar, P. and Larédo P. (2002) Innovation and research policy in France (1980-2000) or the disappearance of the Colbertist State, Research Policy, 31, 1, pp.55-72.

Nelson R. R. and Winter S. G. (1982) An Evolutionary Theory of Economic Change, Harvard U.P.

Oudot J.M. (2007) Choix contractuels et performances. Le cas des contrats d'approvisionnement de défense, thèse de l'Université Paris I Panthéon-Sorbonne, Paris.

Prencipe A. (1997) Technological Capabilities and Product Evolutionary Dynamics: a case study from the aero engine industry, Research Policy, 25, pp.1261-1276.

Prencipe A. (2000) Breath and depth of technological capabilities in COPS: the case of aircraft engine control system, Research Policy, 29, pp.895-911.

Rosenkopf L. and Tushmann M.L. (1998) The coevolution of community networks and technology: Lessons from the flight simulation industry, Industrial and Corporate Change, 7, pp.311-346.

Seo M.G. and Creed D. (2002) Institutional contradictions, praxis, and institutional change: a dialectical perspective, Academy of Management Review, 27 (2), pp. 222-247.

Serfati C. (2000) The place of the French arms industry in its national system of innovation and in the governmental technology policy, in The Place of the Defence Industry in National Systems of Innovation, Reppy J. (ed), Cornell University Press, pp.71-95.

Serfati C. (2001) The adaptability of the French armament industry in an era of globalization, Industry and Innovation, 8, $\mathrm{n}^{\circ} 2$, pp.221-239.

Serfati C. (2008) Financial dimensions of transnational corporations, global value chain and technological innovation, Journal of Innovation Economics, 2 (2), pp.35-61.

Simon H.A. (1991) Sciences des systèmes, Sciences de l'artificiel, Afcet Systèmes, Dunod, Paris.

Stincombe A.L. (1965) Social structure and organizations, in March J.G (ed), Handbook of Organizations, Rand-McNally, Chicago, pp.142-193.

Ulrich K. (1995) The role of product architecture in the manufacturing firm, Research Policy, 24(3), pp.419-440.

Verdier E. (2006), Learning industry against knowledge economy lessons from the French case, in Lorenz E. and Lundvall B.A (eds), How Europe's Economies Learn: Coordinating Competing Models, Oxford, Oxford University Press, 280-313. 
Versailles D.W. (2005) Le maître d'œuvre dans les programmes d'armement : de l'émergence à la consolidation des réseaux de connaissances, Revue d'Economie Industrielle, décembre, pp.83-105.

Walker W. and Gummet P. (1993) Nationalism, Internationalism and the Future of the European Defence Market, Institut d'Etudes Stratégiques (ed), UEO. PARIS.

Wang Q. and Von Tunzelmann N. (2000) Complexity and the functions of the firm, Research Policy, 29, pp.805-818.

Such as the DARPA -Defense Advance Research Projects Agency- and the DHS -Department of Homeland Security-.

2 The study of the interdependencies between the different arms systems shows that the operational requirements of different platforms are defined in relation to one another, making the constraints of interoperability between the different subsystems all the more important.

This programme, launched in 1997, integrates new data link software and systems; it is a systems of system designed to link all the French Air Force's weapons systems. The DGA delegated the task of designing 
the technological architecture for this programme to an industrial consortium comprising Aerospatiale Matra (later EADS) and Thomson CSF (later Thales), which jointly act as LSI.

We refer to the "system of systems integration" or the "architecture systems integration" because this third level of integration "is now most ardently pursued by defence-oriented organizations" (Gholz, 2003: 281). The two other levels are the weapon systems integration and the platform integration.

In Europe, the EDA has tried to increase collaborations and scientific co operations. These later are still very much constrained by national regulations and lack of political willingness. For instance, in order to transfer technology between firms located in different countries, firms belonging to the same company have to conclude an export contract. National rules remain important impeding such Europeanization to occur in the defence related production. About privatization and Europeanization of the defence industry see Serfati (2001). About political conception and political visions among European countries see Walker and Gummett (1993) and Fligstein (2006).

$6 \quad$ The architecture of a system specifies the different sub-systems or modules comprising a system, as well as the relations between these entities. And as Simon (1991) shows, the creation of such an architecture requires a process of decomposition of the functions into sub functions.

According to Ulrich (1995), when a complex system can be subdivided into autonomous subsystems (modules), the latter can be connected by coupled interfaces (integral architecture) or decoupled interfaces (modular architecture).

Usually this means that the state determines the final specification, needs, objectives and constraints of the project.

9 The DGA currently employs 19,500 people (6,500 management and executive staff; 9,600 scientists and test, trial experts, and 3,400 maintenance staff.)

10 According to Henderson and Clark (1990) : (i) component knowledge is knowledge about each of the core design concepts and the ways in which they are implemented in a particular component; (ii) architectural knowledge is knowledge about the ways in which the components are integrated and linked together into a coherent whole.

11 Cost-plus contracts applied to R\&D phases of programmes and included 1) development costs, 2) contractual mechanisms allowing both the calculation of the mark-up (profit margin) made by the firm on the $R \& D$ phases and their integration in the global amount of the contracts.

12 According to Kirat et al. (2003), in 1994, the negotiated procedure was used for $94 \%$ of total orders, and $80 \%$ of these contracts were awarded without published calls for tender.

13 For instance, Thales should have an export agreement for technologies exchange even between subsidiary companies (Thales UK and Thales France).

14 Expertise from various institutions, such as the Directorate of Military Applications of the CEA, ONERA and CNES, was mobilized by the military services.

15 At that time, the term 'project-owner' has been overtaken by 'procurement agency'.

16 For instance from 1994 to 2000, large firms (more than 500 employees) remain whereas SMEs (up to 100 employees) stay constantly unrepresented in the Defence R\&D execution (figures in comparisons with the global execution of R\&D for the French firms). For details, see Guillou et al (2005) final report.

17 DGA's spending on exploratory projects as part of its scientific research and innovation mission, is currently $€ 12$ million per annum. Although the sums available are limited, they are laying the foundations for a new orientation of military R\&D policy.

18 Dual-use projects are mainly directed towards CNES for space research, and towards calls for propositions implementing innovative cooperation between universities and small firms

19 From 2003, reinforcement of technical capabilities once again became a DGA priority.

20 DAM: Military Applications Directorate of the CEA. A new agreement was signed between the DGA and the DAM. Expanding the missions and tasks of CEA/DAM to include scientific fields that are not exclusively related to nuclear science, allows DGA to mobilize their expertise. DAM acts as an interface and provides the strategic orientations for the activities conducted by universities and public R\&D centres in scientific and technological fields directly related to defence. ONERA contributed to the development of miniature drone demonstrators through a consultancy arrangement (Fromion, 2005: 46).

21 This aspect emerged in interviews with managers at ONERA, CEA, in industry and the military services.

22 These relations have taken the form of institutionalized meetings between the 'elites' in the political and economic spheres. These exchanges are rather formal. A more «open and free » relationship between DGA and industry is developing around upstream projects, but this relative openness is limited to a few projects where trust among the main actors has been developed.

${ }_{23}$ For instance LTO such as SARR (Systèmes d'Armes pour le Renseignement et la Reconnaissance) specialized in the elaboration of information and communication systems for command and control networks, 
and BOA (Bulle Operationnelle Aero-terrestre) focuses on the French Army air-ground and ground-ground communications.

$24 \quad$ DRET was excluded from the DGA in 1997.

25 It is estimated that between 1988 and 2000, the workforce was reduced by $30 \%$; this does not take account of the change of status of the Department of Naval Construction to a government corporation.

26. This was the case for the SCCOA programme in whose technical design and technical evaluation DGA played no part, even after the 2003 reform.

27 Armaments engineers occupied key positions in the defence programmes at CEA, CNES, ONERA, DGA and the firms involved in arms design. The influence of these armaments engineers included definition of strategic concept in the fields of the military and foreign policy. However, this model functioned as a closed network (Giovachini, 2000).

28 Certain technological fields, such as radar technology and electronics, left the fold of the DGA's expertise very early. However, there are some exceptions where DGA's engineers worked on research programmes upstream in firms in order to enable better monitoring of the project. This mobility has been reduced compared to before the 1997 reform.

29 Scope here refers to the many technological fields in which the DGA is currently active. In depth refers to the mastery of two main dimensions: 1) -the different stages in the process of development of an arms programme;.2)- the knowledge related to the combination of the programme's components (architectural knowledge) and the knowledge concerning each component (component knowledge). 